
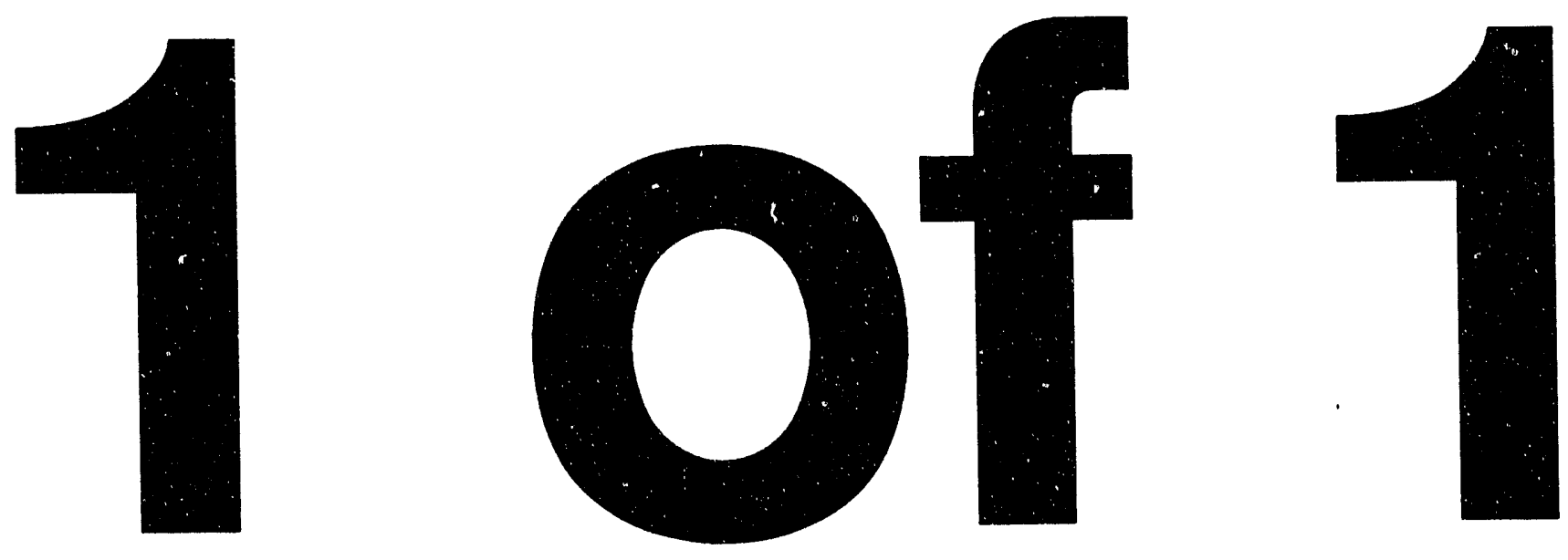
QUARTERLY TECHNICAL PROGRESS REPORT NO. 18

For

a) 171995

$\frac{4-3}{3}$ ENGINEERING DEVELOPMENT OF $\bullet$,
ADVANCED PHYSICAL FINE COAL CLEANING TECHNOLOGIES -

\section{FROTH FLOTATION}

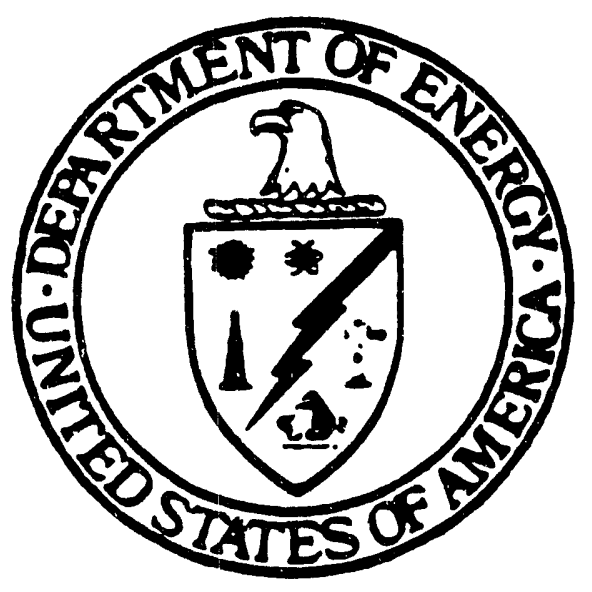

Prepared for

U.S. DEPARTMENT OF ENERGY

PITTSBURCH ENERGY TECHNOLOGY CENTER Pittsburgh, Pennsylvanla

CONTRACT NUMBER

DE-AC22-88PC88881

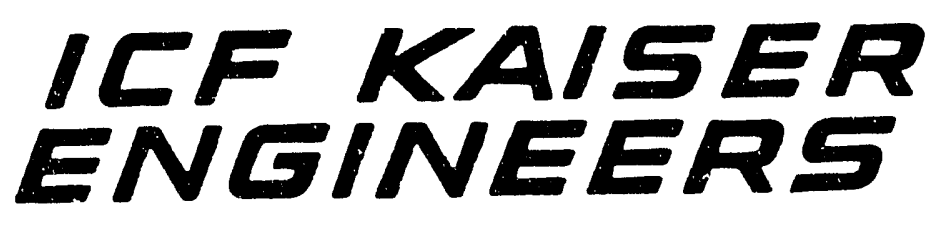

With

Ohio coal Development Office

Babcock \& Wilcox

consolldation coal company

center for Research on Sulfur in coal

EIMCO Process Equipment Company

IIIInols state Geologic Survey

Kentucky Energy Cabinet Laboratory

Virginla Polytechnic Institute \& State University 
QUARTERLY TECHNICAL PROGRESS REPORT NO. 18

FOR PERIOD

JANUARY 1, 1993 THROUGH MARCH 31, 1993

DOE CONTRACT \#DE-AC22-88PC88881

ICF KAISER ENGINEERS JOB NO. 88107<smiles>C1CCCCC1</smiles>

"This report was prepared as an account of work performed by ICF Kaiser Engineers under sponsorship of the United States Government. Neither the United States nor the United States Department of Energy, ICF Kaiser Engineers, its subcontractors, nor any of their employees, makes any warranty, express or implied, or assumes any legal liability or responsibility for the accuracy, completeness, or usefulness of any information, apparatus, product, or process disclosed, or represents that its or usefulness infringe privately-owned rights. Reference herein to any specific comercial product, process, or service by trade name, mark, manufacturer, or otherwise, does not necessarily constitute or imply its endorsement, recommendation, or favoring by the United States Government or any agency thereof. The views and opinions of authors expressed herein do not necessarily state or reflect those of the United States Government or any agency thereof." 
TABLE O $_{-}-$CONTENTS

PAGE

1.0 INTRODUCTION

1.1 Scope of this Document

1.2 Overall Project Scope

1.3 Work Executed at Different Locations 3

2.0 TASK 2 PRELIMINARY CONCEPTUAL DESIGN

2.1 Overview and Scope 4

2.2 Review of Work Completed This Quarter 4

$\begin{array}{llll}3.0 & \text { TASK } 3 & \text { CRITICAL AREA DETERMINATION } & 4\end{array}$

3.1 Overview and Scope 4

3.2 Review of Work Completed This Quarter 5

4.0 TASK 4 TEST PLAN FORMULATION

4.1 Overview and Scope 5

4.2 Review of Work Completed This Quarter 6

5.0 TASK 5 BENCH-SCALE PROCESS TESTING

5.1 Overview and Scope 6

5.2 Review of Work Completed This Quarter 7

$\begin{array}{lll}6.0 & \text { COMPONENT AND UNIT OPERATIONS DEVELOPMENT } & 7\end{array}$

6.1 Overview and Scope 7

6.2 Review of Work Completed this Quarter 8

7.0 EVALUATION OF BENCH-SCALE AND COMPONENT TEST RESULTS 8

7.1 Overview and Scope $\quad 8$

8.0 REVISED CONCEPTUAL DESIGN OF SEMI-WORKS PLANT 9

8.1 Overview and Scope 9

8.2 Review of Work Completed this Quarter 9

9.0 POC MODULE DESIGN 9

9.1 Overview and Scope 9

9.2 Review of Work Completed this Quarter 10

$\begin{array}{lll}10.0 & \text { POC MODULE FABRICATION } & 10\end{array}$

10.1 Overview and Scope 10

10.2 Review of Work Completed this Quarter 10

iósiogejatriynep $\quad$ page 
TABLE OF CONTENTS

(cont inued)

PAGE

$\begin{array}{lll}11.0 & \text { POC INSTALLATION AND START-UP } & 10\end{array}$

11.1 Overview and Scope 10

11.2 Review of Work Completed this Quarter 11

12.0 POC TEST PLAN FORMULATION 12

12.1 Overview and Scope 12

12.2 Review of Work Completed this Quarter 13

13.0 POC OPERATION 13

13.1 Overview and Scope 13

13.2 Review of Work Completed this Quarter 13

14.0 TASK 14 THROUGH TASK 16

14.1 Review of Work Completed this Quarter 18 


\section{LIST OF FIGURES}

FIGURE

Figure

\section{TITLE}

1.1

Project Organization Chart 


\section{LIST OF TABLES}

TABLE

1.1

13.1

13.2

13.3

13.4

\section{TITLE}

Task and the Responsible Team Member

Comparison of Laboratory Results

Heavy-media Test Results

Hydrocyclone Test Results

Conventional Flotation Test Results 
A study conducted by Pittsburgh Energy Technology Center of sulfur emissions from about 1,300 United States coal-fired utility boilers indicated that half of the emissions were the result of burning coals having greater than 1.2 pounds of $\mathrm{SO}_{2}$ per million BTU. This was mainly attributed to the high pyritic sulfur content of the boiler fuel. A significant reduction in $\mathrm{SO}_{2}$ emissions could be accomplished by removing the pyrite from the coals by advanced physical fine coal cleaning.

An engineering development project was prepared to build upon the basic research effort conducted under a solicitation for research into Fine Coal Surface control. The engineering development project is intended to use general plant design knowledge and conceptualize a plant to utilize advanced froth flotation technology to process coal and produce a product having maximum practical pyritic sulfur reduction consistent with maximum practical BTU recovery.

\subsection{Scope of this Document}

The Department of Energy (DOE) awarded a contract entitled "Engineering Development of Advanced Physical Fine Coal Cleaning Technology - Froth Flotation", to ICF Kaiser Engineers with the following team members, Ohio Coal Development Office, Babcock and Wilcox, Consolidation Coal Company, Eimco Process Equipment Company, Illinois State Geological Survey, Virginia Polytechnic Institute and State University, Process Technology, Inc. The organizational chart for this project is presented in Figure 1.1.

This document a quarterly report prepared in accordance with the project reporting requirements covering the period from July 1,1992 to September 30, 1992. This report provides a summary of the technical work undertaken during this period, highlighting the major results. A brief description of the work done prior to this quarter is provided in this report under the task headings.

\subsection{Overall Project Scope}

The overall project scope of the engineering development project is to conceptually develop a commercial flowsheet to maximize pyritic sulfur reduction at practical energy recovery values. This is being accomplished by utilizing the basic research data on the surface properties of coal, mineral matter and pyrite obtained from the Coal Surface Control for Advanced Fine Coal Flotation Project, to develop this conceptual flowsheet. The conceptual flowsheet must be examined to identify critical areas that need additional design data. This data will then be developed using batch and semicontinuous bench scale testing. In addition to actual bench scale testing, other unit operations from other industries processing fine material will be reviewed for potential application and incorporated into the design if appropriate.

The conceptual flowsheet will be revised based on the results of the bench scale testing and areas will be identified that need further larger scale design data verification, to prove out the design. The 


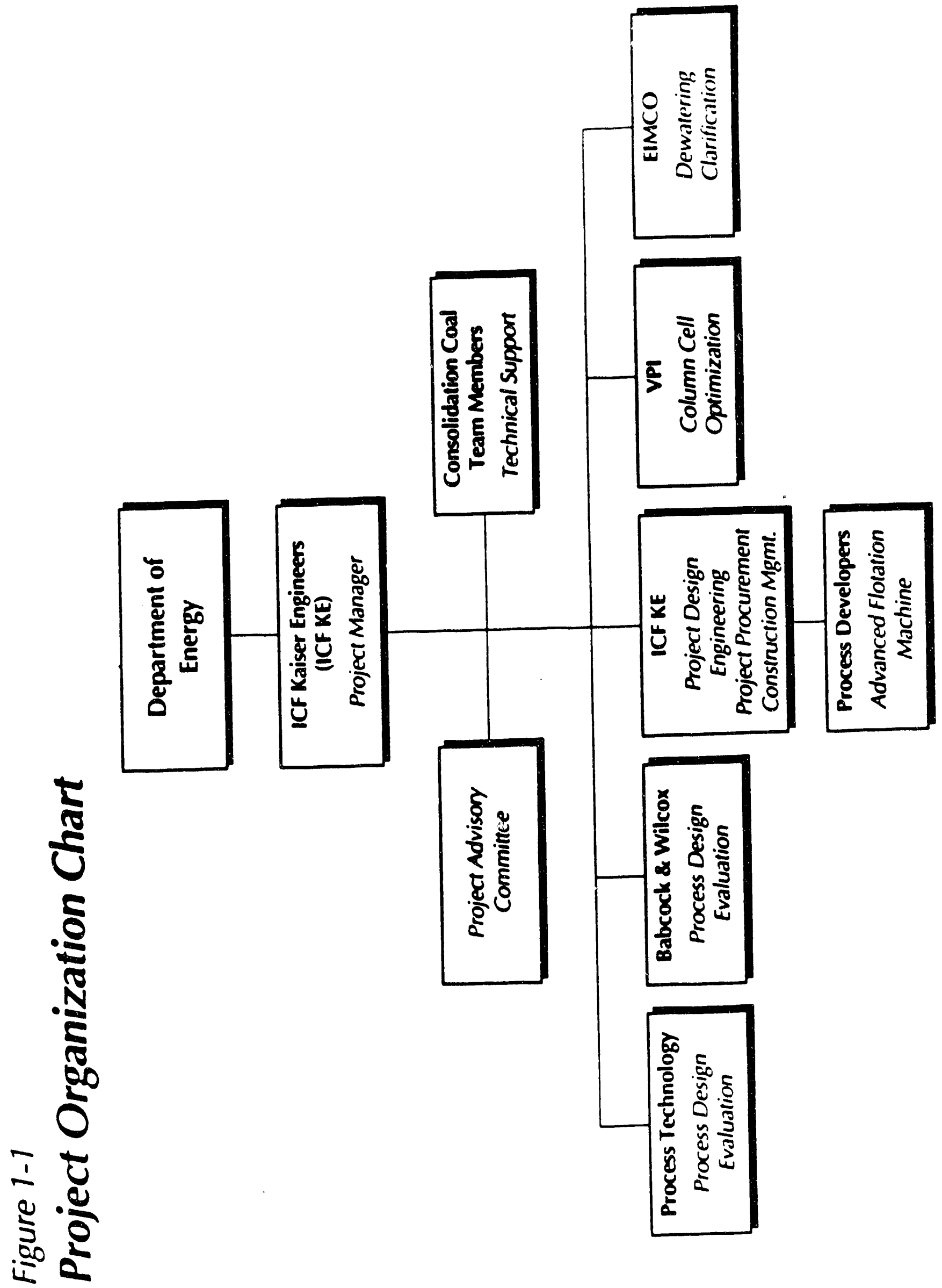


proof-of-concept will be accomplished by designing, constructing, operating and testing a 2-3 ton per hour proof-of-concept plant. This plant will be designed for continuous operation and will include two consecutive 5 days, 24 hour per day runs on each of the three test coals to demonstrate process performance on a commercial basis.

The data from the basic research on coal surfaces, bench scale testing and proof-of-concept scale testing will be utilized to design a final conceptual flowsheet.

The economics of the flowsheet will be determined to enable industry to assess the feasibility of incorporating the advanced fine coal cleaning technology into the production of clean coal for generating electricity. This concept should provide an ability to reduce sulfur oxide emissions more economically than FGD systems when compared on a dollar per ton of sulfur removed basis.

1.3 Work Executed at Different Locations

The project team consists of research and engineering groups at ICF Kaiser Engineers, Babcock and Wilcox, Consolidation Coal Company, Eimco Process Equipment Company, Illinois State Geological Survey, Virginia Polytechnic Institute and State University, Process Technology, Inc. and Michigan Technological University Institute of Materials Processing with ICF Kaiser Engineers as the prime contractor with DOE. The work being conducted by different organizations is based upon their area of expertise and this has been incorporated into the project Work Plan. The work undertaken by the different organizations is identified in Table 1.1. This report is prepared in an integrated manner combining work done by each organization by task. This is considered to be a more effective way of presenting the technical data developed by each organization.

Table 1.1

Task and the Responsible Team Member

$\begin{array}{ll}\text { Task } & 1 \\ \text { Task } & 2 \\ \text { Task } & 3 \\ \text { Task } & 4 \\ \text { Task } & 5 \\ \text { Task } & 6 \\ \text { Task } & 7 \\ \text { Task } & 8 \\ \text { Task } & 9 \\ \text { Task } & 10 \\ \text { Task } 11 \\ \text { Task } 12 \\ \text { Task } 13 \\ \text { Task } 14 \\ \text { Task } 15 \\ \text { Task } 16\end{array}$
Project Planning

Preliminary Conceptual Design

Determination of Critical Areas

Test Plan Formulation

Bench Scale Testing

Component Development

Analysis of Test Results

Revised Conceptual Design

POC Module Design

POC Procurement and Fabrication

POC Installation and Startup

POC Test Plan Formulation

POC Testing and Operation

Analysis of POC Test Results

Final Conceptual Design

POC Module Removal
ICF KE

ICF KE, B\&W, EIMCO, TSG, TAC

ICF KE, B\&W, EIMCO, TSG, TAC

ICF KE, B\&W, EIMCO, TSG

ICF KE, B\&W, EIMCO, PTI, TSG, TAC

VPI, TSG

ICF KE, B\&W, EIMCO, VPI, TSG

ICF KE

ICF KE, B\&W, EIMCO, TSG, TAC

ICF KE

ICF KE, B\&W, EIMCO, TSG

ICF KE, B\&W, EIMCO, TSG, TAC

ICF KE, B\&W, EIMCO, TSG

ICF KE, B\&W, EIMCO, TSG

ICF KE, B\&W, EIMCO, TSG

ICF KE 


\subsection{TASK 2 PRELIMINARY CONCEPTUAL DESIGN}

\subsection{Overview and Scope}

The previous completion of this task resulted in the preliminary conceptual design of a 20TPH semi-works advanced froth flotation facility. The non-site-specific plant was designed using the best available information and technology to achieve continuous, steady-state process operation with $90 \%$ availability. The process plant is a fully instrumented, integrated, stand-alone facility. A greenfield site was assumed for the plant.

Throughout the project, the work was organized along a task/sub-task basis with each sub-task logically assigned to provide necessary information for the next sub-task, ultimately resulting in completion of the conceptual design. For Task 2, the first sub-task determined the design criteria needed to meet or exceed the advanced froth flotation process specifications. At completion, work under this sub-task provided information to design the flowsheet of the process, and provided an energy and material balance of all process streams. A list of all major process equipment was prepared and used as a basis for a factored estimate for the capital, operating and maintenance costs of the semi-works process and plant.

ICF Kaiser Engineers, assisted by the project sub-contractors and Technical Support Group, was responsible for the performance and completion of this task. This conceptual design is the basis for Tasks 3, 4, 5, and 6 and will be revised in Task 8 for use as a basis for the 2-3TPH POC module design in Task 9.

\subsection{Review of Work Completed This Quarter}

On August 15, 1989, DOE approved Task 1.2 as submitted. With this as a basis, ICF KE and the team members proceeded with the remainder of the project. No additional work was planned nor completed during this quarter.

\subsection{TASK 3 CRITICAL AREA DETERMINATION}

\subsection{Overview and Scope}

Work performed during the conceptual design of Task 2 identified areas where uncertainties exist in the design of the unit operations for the advanced froth flotation process. Some of these problem areas could not be solved based on currently available information or technology. The objective of this task was to determine those critical areas where more information would be necessary and out 7 ine the work needed to obtain the design information.

A design deficiency list was generated, and the project team determined the parameters needed for final design of the unit operation - either by further engineering analysis or by experimental data obtained from bench-scale tests. Other solids processing industries, such as phosphate and clay beneficiation, 
were examined to assess the means by which they effectively process ultra fine particles.

Each identified design deficiency was then ranked according to its relative importance to the successful continuous operation of the advanced froth flotation process. Both a technical and economic analyses of the consequences of not being able to gather the required design information for each deficiency was evaluated.

ICF Kaiser Engineers, Consolidation Coal and the other members of the Technical Support Team (B\&W, VPI and EIMCO) have contributed to this task. The process deficiencies identified in this task will be addressed in Tasks 4, 5, and 6 through additional engineering computation and analysis and experimental techniques.

3.2 Review of Work Completed This Quarter

The final report of this task has been submitted to DOE. No additional work was planned nor completed during this quarter.

\subsection{TASK 4 TEST PLAN FORMULATION}

\subsection{Overview and Scope}

Work completed in this task produced the criteria for additional engineering analysis, computation and detailed experimental benchscale testing for areas of uncertainty identified in Task 3 . The engineering analysis, computation, bench-scale testing and component development was formulated to produce necessary design information to define a commercially operating system.

In order to produce the required information by means of bench-scale testing and component development, a uniform coal sample was procured. After agreement with $\mathrm{DOE}$, a selected sample of coal from those previously listed was secured.

The test plan was developed in two parts. The first part listed procedures for engineering and computational analyses of those deficiencies previously identified that could be solved without bench scale testing. Likewise, the second part prepared procedures for bench-scale testing and component development for those deficiencies previously identified in Task 3.

The first part, engineering analysis and computation, provided for means of employing presently know theory from other industries to address deficiencies. This included examinations of 1 iterature and contacting proven experts and operating personnel in fields related to this deficiency. From the information gathered, engineering calculations will be utilized to resolve this type of deficiency.

The second part, bench-scale testing and component development, became necessary when the part one information was unavailable or when the theory had never been commercially applied. Justification for the test work was provided to show that technical data and process needs could only be obtained by test work and that the test 
work results would produce necessary information to define a commercially operating system.

The test work planned was based upon non-continuous and/or semicontinuous bench-scale units of general laboratory design and would include on?y those unit operations identified as deficiencies in Task 3.

The detailed, quantified tests addressed obtaining data necessary for solving problems uncovered in the deficiency review. Each identified deficiency had a $p l a n$ developed to address the reason for the testing, the means for the test matrix to obtain results and the expected results. Each test plan established procedures, adhering as much as possible, to known and industry-acceptable procedures for sampling and data collection. Raw data collection would be reduced to minimize expenses and to better be able to compare resuits and obtain meaningful information, especially scale-up factors.

The Development Test Plan for both parts one and two contained schedules, manpower requirements, and resources necessary to obtain information to define a commercially available system.

The plan for use of the team members was developed to comply with the results of the DOE uniform coal sampie procurement and storage procedures. The quantity of coal necessary for each testing program was calculated. A sample of all three of the referenced coals was to be obtained, preferably from the same source as the Surface Control contractor. This coal would be stored and handled as outlined in the coal procurement and storage plan. These procedures, when properly followed, should minimize physical and chemical changes to the raw coal.

\subsection{Review of Work Completed This Quarter}

The Task 4 Report was submitted to DOE as a final report. No additional work was planned nor completed during this quarter.

\subsection{TASK 5 BENCH-SCALE PROCESS TESTING}

\subsection{Overview and Scope}

The overail goal of Task 5, "Bench-Scale Process Testing" is to develop the necessary unit operation design and process performance data required to 1) reduce or eliminate the technical and engineering uncertainties of the preliminary 20TPH advanced location semi-works plant and 2) design, build and operate a 2-3 TPH advanced flotation POC module.

The unit operation performance and process design information required to support development of the advanced flotation process is being examined in a multi-tier program at B\&W and Process Technology, Inc. Laboratory scale studies are being conducted in several key process areas - conventional precleaning of the raw coat, microgrinding of the pre-cleaned coal, advanced froth flotation of the fine coal and dewatering of the product streams. 
The results of these studies are then being used to guide small, semi-continuous and continuous testing of the key unit operations at approximately $100 \mathrm{lb} / \mathrm{hr}$.

The bench-scale and semi-continuous process design evaluation test programs will provide detailed information for developing process material and energy balances. The material balance data will be used to correctly design and size the equipment for the POC module. The energy balance information will allow for estimation the cost effectiveness of the design.

The bench-scale test programs will also identify the optimum conditions for microgrinding the coal for maximum puritic sulfur rejection in advanced flotation and the mnct nromisilis advanced flotation technique which will then be integrated into the uverall processing scheme. The $100 \mathrm{lb} / \mathrm{hr}$ test program will provide verification of the laboratory tests results and demonstration that these results can be scaled-up for application in the 20TPH semiworks plant design.

Both the bench-scale, semi-continuous and continuous process design evaluation tests will serve as critical reviews of the preliminary process flowsheet. Process deficiencies and limitations discovered in these programs will require modification of the original conceptual flowsheet. This information will aid in identifying solutions to the successful implementation of advanced flotation technology.

The bench-scale and process testing consists of eleven major subtasks performed over a period of 12 months.

\subsection{Review of Work Completed This Quarter}

This task has been completed and the results of this task are reported in the Task 7 report. No additional work was planned nor completed during this quarter.

\subsection{COMPONENT AND UNIT OPERATIONS DEVELOPMENT}

\subsection{Overview and Scope}

The Task 6 effort involves three main elements including column cell development, flotation circuit testing and flotation cell modeling. The work outlined is to research column designs and operation parameters in developing an optimized column flotation cell (OCFC) to meet the overall program objectives. The test results obtained through this effort will be evaluated against the results obtained from the round-robin test program in Task 5 . Any design parameters or operating conditions that are unique with the round-robin test winner that were not evaluated as part of the optimized column development work will be reviewed and tested so as to incorporate all possible scenarios in presenting DOE with the best available flotation process for use in the 2 to 3 ton per hour POC. 
Following development of the OCFC, various flotation circuit configurations will be evaluated determine the "best" circuit design for the 2 to 3 ton per hour POC. Single and multiple stage flotation, grab and run, rougher/scavenger/cleaner, etc., test circuits will be tested as part of this effort. Upon completion of this test work, the "best" possible flotation cell will have been tested in a number of possible flotation circuit designs to possibly provide the "best" flotation approach in meeting the design criteria.

In conjunction with the flotation test effort, model development work will be conducted to provide a tool in evaluating the various flotation circuit configurations and in predicting flotation performance. The model will be useful in selecting operating conditions in the POC and in evaluating the performance of the POC.

\subsection{Review of Work Completed this Quarter}

This task has been completed and the results of this task are reported in the Task 7 Report. No additional work was planned or completed during this quarter.

\subsection{EVALUATION OF BENCH-SCALE AND COMPONENT TEST RESULTS}

\subsection{Overview and Scope}

A bench-scale and component testing report was prepared and submitted to DOE after completing Task 5 and Task 6.

The report included the preparation, presentation and analys is of all the experimental data obtained in the bench-scale and component unit operations, development and testing. A comparison of the results obtained with the expected limitations and deficiencies that occurred from bench-scale testing was compiled.

Following the evaluation of the bench-scale and component testing results, a residual needs analysis was prepared. This was prepared after comparing results learned in Tasks 5 and 6 with the original residual needs analysis.

Finally, a bench-scale testing summary was prepared. It specificaily addressed the results of the bench-scale component testing in respect to the information necessary to define a commercially operating system. This included equipment selection, sizing, evaluation and operation to achieve both coal cleaning as well as the cost of system operation.

\subsection{Review of Work Completed this Quarter}

This task has been completed and the Task 7 Report submitted to DOE in its final version. No additional work was planned or completed during this quarter. 


\subsection{REVISED CONCEPTUAL DESIGN OF SEMI-WORKS PLANT}

\subsection{Overview and Scope}

Following DOE authorization to proceed with this task, the preliminary conceptual design of a 20TPH semi-works plant (Task 2) was redesigned from all information available at this point in the project. This update of the conceptual design incorporated information derived about fine grinding, advanced froth flotation, and dewatering in Tasks 5 and 6 . The summary report produced in Task 7 describing bench-scale test results and component development was used as a basis.

This task complied with all of the design requirements discussed in Task 2. The process flowsheet was updated with complete energy and material balances for all process flowstreams. The equipinent list was updated and supplied the base for a recalculation of the factored estimate of the capital, operating and maintenance costs. In addition, differences between the designs in Task 8 and Task 2 was highlighted and their effects on process and plant design credibility, efficiency, maintenance, operation, complexity, control, performance, and economics were discussed.

ICF Kaiser Engineers, with assistance from its sub-contractors and the Technical Support Group, were responsible for the completion of this task. This design will serve as a basis for the POC design in Task 9 and the final semi-works design in Task 15.

\subsection{Review of Work Completed this Quarter}

This task has been completed and a draft report submitted to DOE. No additional work was planned or completed during this quarter.

\subsection{POC MODULE DESIGN}

\subsection{Overview and Scope}

In order to develop additional confidence in the conceptual design of the advanced froth flotation circuit, a 2-3 TPH Proof-of-Concept (POC) facility was necessary. During operation of this facility, the ICF KE team will demonstrate the ability of the conceptual flowsheets to meet the program goals of maximum pyritic sulfur reduction coupled with maximum energy recovery on three DOE specified coals. The POC circuit was designed to be integrated into the Ohio Coal Development's facility near Beverly, Ohio.

OCDO's facility will provide the precleaning unit operations and ICF KE will add the advanced froth flotation circuitry. The work in this task will include the POC conceptual design, flowsheet development, equipment list, fabrication and construction drawings, procurement specifications and bid packages and a facilities estimate at the completion of design. After DOE approval, the design was finalized for the next task. 


\subsection{Review of Work Completed this Quarter}

All of the subtasks for Task 9 have been completed except the Task 9 report. The only remaining items are the writing of this task report in and orderly fashion and presentation to DOE. No additional work planned nor completed during this quarter.

\subsection{POC MODULE FABRICATION}

\subsection{Overview and Scope}

The overall objective of this task is to obtain the equipment, materials and shop labor to fabricate and assemble each of the individual modules which constitute the POC Module. The ICF KE procurement team will solicit bids, place orders, and expedite all vendors, materialmen and fabricators. Procurement will utilize the drawings and specifications produced in Task 1.9 as the basis for these activities. At the completion of the assembly procedure, a ICF KE representative will inspect and perform a functional check of each module before it leaves the shop.

Several sub-tasks have been identified for their importance in the successful completion of this task. Work will include placing purchase orders, procurement of the equipment and materials, fabrication of the modules, functionally checking the modules, shipping the modules to the jobsite and preparing the installation and maintenance manuals.

\subsection{Review of Work Completed this Quarter}

All subtasks for Task 10 have been completed except for minor purchases of minor equipment such as electrical relays and small completion items. No additional work was planned or completed during this quarter.

\subsection{POC INSTALLATION AND START-UP}

\subsection{Overview and Scope}

This task covers the functions necessary to install and successfully start-up the POC module at the jobsite. The installation was carried out by an installation subcontractor with construction management provided by ICF KE. The start-up was supervised by ICF KE and conducted using process engineers from the entire team and craft labor supplied by the installation subcontractor.

This task includes several major subtasks which was carried out to assure a successful, on-schedule installation and start-up. ICF KE will conduct work on installation and interconnection of the modules, preparation of start-up plans and procedures, the start-up functions and the finalization of the operations manual.

DOE's TPO was kept informed of construction progress and has access to the site for inspection of the work. ICF KE's construction manager was assigned prior to the start of construction activities 
and maintained the job progress through on-site assessment of the work and was using the construction schedule produced in Task 9 for control.

\subsection{Review of Work Completed this Quarter}

The construction of the DOE POC at the OCDO facility was completed during the first month of this quarter. The construction was completed in a four-month period, including fabrication, foundations, erection, and sheeting and siding. In addition to the mechanical work, the electrical installation was also completed.

All of the equipment was prepared with proper lubrication, rotation of all motors verified, and each unit operation was started locally and remotely by the PLC computer control system. The instruments were tested for proper calibration and signals verified at the PLC monitors. The density gauges were not calibrated during this time frame. The gauges require a cert ified Nuclear Regulatory Commission technician who arrived in February to calibrate the units.

At this time, the nuclear density gauges calibration was attempted. A problem developed in that not enough "counts" were being recorded to meet the accuracy required. The manufacturer was contacted, and steps are ongoing to remedy this problem.

The leads from all of the motor control centers were disconnected, and the computer was used to check interlocking. This form of checking does not require the physical operation of the electrical equipment to test the interlocking system. Minor modifications were made to the program to improve the automatic control of the DOE POC facility.

The water balance of the OCDO facility, integrated with the DOE POC facility, was completed in about one week. During the week of February 8, 1993, the plant circuitry was operated at a feed rate of five TPH, with Meigs Creek No. 9 coal supplied by the host at the facility. The Meigs Creek coal is a very high clay content raw coal, and for this reason, numerous plugging problems occurred in the OCDO portion of the facility.

During the week of February 15, 1993, a major disruption occurred when the Gundlach cagepactor failed. This resulted in a one-week down time period while the machine was disassembled, repaired, and re-assembled for operation.

During the week of February 22, 1993, all of the unit operations were operated to the point that the precleaning circuit equipment could be tested. Although no testing was actually completed, all unit operations, except the hyperbaric filter, were operated at designed tonnage and flowrate.

The Meigs Creek coal again caused problems with chute plugging, and the decision was made to remove this coal from the raw coal bin and delay operation until March 8, 1993 when Pittsburgh No. 8 coal could be furnished. 
The start-up and debugging of the system was completed during the month of February. However, several operating problems for the final dewatering equipment prevented integrating these unit operations into the system. These unit operations were the hyperbaric filter for the clean coal and the refuse belt press for the fine refuse dewatering. It was determined that testing could begin per the test plan and bypass these unit operations while remedies to the problems were implemented.

The hyperbaric filter was experiencing plugging problems inside the pressure vessel, as well as the discharge gates and chute arrangements. In addition, and contributing to the gate plugging problem, was the fact that the unit was using excessive amounts of air during operation. The excessive air was more than the capacity of the air compressor, which would lose pressure and not operate the discharge gates.

At the end of this quarter the KHD personnel agreed to make every effort to improve the operation of the filter, and stated that by the end of April or early May, the filter should be ready for proper operation after modifications that require a redesign.

The refuse belt press operated properly except that not enough flocculant could be added to the feed to improve free drainage. This caused an excessive amount of solids in the filtrate. The remedy was to purchase and install a new, larger flocculant pump. This was ongoing at the end of this report quarter.

Neither of these unit operations would prevent beginning the test plan because both units could be bypassed. A solid bowl centrifuge would dewater the clean coal, and the fine refuse would be disposed of by pumping the thickener underflow to an impoundment for disposal.

\subsection{POC TEST PLAN FORMULATION}

\subsection{Overview and Scope}

The project team will coordinate its expertise and develop a testing plan that will provide performance data, quality data, scale-up data and operating data. The plan was submitted to DOE for approval after completion of Tasks 9 and 10 .

This plan, after approval/revisions, will become the final test plan. The test plan will include long term testing, steady-state operation and effects of recycle operation. The testing program will demonstrate $90 \%$ onstream capability, evaluate process control instrumentation, develop information for scale-up, demonstrate compliance with regulatory requirements, evaluate materials of construction, and determine process economics. Ancillary information such as quality of waste stream materials was gathered. 
The finalized plan will include a budget and schedule to complete all required tests and to produce batches of material for testing of beneficiated coal.

\subsection{Review of Work Completed this Quarter}

No additional work was planned or completed during this quarter.

\subsection{POC OPERATION}

\subsection{Overview and Scope}

This task is the actual demonstration of the advanced froth flotation technology. All previous work has led to this task. ICF KE technicians and process engineers from the team will operate the plant over a 10 month period to demonstrate the capability of the technology to remove $85 \%$ of the pyritic sulfur from three different test coals while covering at least $85 \%$ of the as-mined coal's energy content.

Six major subtasks have been included to better define the overall work scope for this task. The ICF KE team will test the Pittsburgh \#8 seam, the IIlinois \#6 seam and the Upper Freeport seam; the team will operate the circuit in a continuous run; the team will analyze all samples generated in those runs and will develop a plan to store and dispose of the coal and refuse products.

All laboratory data generated will be accessible to all team members and the DOE. The TPO will be notified of all run days in advance for the purpose of planning his trips to the site. Sufficient time will be allowed in the test plan, developed in Task 12, to permit quick analysis of data generated from a completed test before continuing tu the next test.

\subsection{Review of Work Completed this Quarter}

The test program for the Pittsburgh No. 8 coal began during March 1, 1993. An arrangement has been made between ICF Kaiser Engineers (ICF KE) and American Electric Power (AEP), who is the host for the DOE POC facility. The arrangement calls for AEP to purchase the raw coal and use the clean coal generated by the DOE POC facility. This arrangement permits the processing of raw coal at a very minimal cost of purchasing the raw coal. However, a compromise had to be reached for the Pittsburgh No. 8 coal. The Ohio Valley Coal Company, where ICF KE acquired the Pittsburgh No. 8 for Task 5 , was not an acceptable supplier. An attempt was made to contract with a CONSOL mine in southeastern Ohio, but the mine was closed after negotiations began. The Pittsburgh No. 8 is being purchased from the Windsor Mine in West Virginia, which is directly across the river from the CONSOL mine.

The change of coal source should not present a problem when comparing the results from Task 5 to Task 13. Some adjustments have to be made while operating the different circuits, but by and large, the coal is very similar. The fact that it is different should add 
further comfort to industry that the advanced flotation process is not coal-specific.

A number of operating problems surfaced during the pre-test familiarization program. The problems were not insurmountable and did not detract from the test plan. These problems had to do with unit operations in the pre-cleaning circuit and the ancillary dewatering equipment after the advanced flotation cell.

The first problem encountered was the production of raw coal crushed to $1 / 4$ inch $x$ zero. The crusher installed to reduce a primary crusher product for $11 / 2$ inch to $1 / 4$ inch top size contained a smooth roll and a herringbone roll for the bottom rolls. After discussion with the manufacturer, a weekend was used to add $1 / 8$ inch beads every two inches along the smooth roll. The results were much improved, but still produced approximately $10 \%$ plus $1 / 4$ inch material.

To remedy the oversize problem, ICF KE installed $1 / 2$ inch opening screen panels on the raw coal screen and, instead of passing directly to the raw coal sump as planned, the raw coal is screened at $1 / 2$ inch. This provided oversize protection, but had the potential for rejecting too much raw coal. Chutework was added to direct the oversize to a middlings crusher that further reduces the raw coal and discharges to the raw coal sump. In this roundabout way, all coal entering the plant is processed at the correct size.

The next problem that developed was a result of the system being closed and water being recycled during the operation of the plant. When testing the heavy media cyclone and hydrocyclone, preliminary reagent additions were fed to the conventional flotation cells. The reagent rates were based on the rates developed during Task 5 . The Task 5 test work was in open circuit and the DOE POC is being operated in closed circuit. The recirculated water became poisoned with flotation reagents, causing froth to develop in every operating sump, to the point that the pumps were cavitating and operation became impossible. On two different occasions during the beginning of the test program, all of the water in the plant was purged and replenished in order to continue plant operation. This problem was addressed in the testing of the conventional flotation to be reported later in this report.

The next problem encountered was the operation of the refuse belt filter press. During the start-up and operation of the belt filter press, it was determined that more flocculation chemicals were required in the feed to the press. This resulted in the procurement of a larger flocculate reagent pump and subsequent installation delays. The press, when operating, produced a conveyable, acceptable moisture product. The problem was the capture rate of the fine refuse. This problem did not lead to any downtime because the belt press can be bypassed.

The next problem was the operation of the hyperbaric filter that is designed to dry the advanced flotation cell product. This unit operation was consuming too much air during operation, as well as 
experiencing continued plugging of the product discharge system. KHD personnel met with ICF KE and has developed a plan to attempt to overcome the operational problems of the hyperbaric filters. However, the remedies will not be implemented until sometime in early May. Again, this is not a problem because the unit can be bypassed if required.

The product from the hyperbaric filter, when operational, is very good. The moisture is $25-28 \%$ on 200 mesh $x$ zero coal and very conveyable. The KHD personnel suggested that once the excess air consumption is remedied, the operating pressure of the hyperbaric filter can be increased which should further reduce the moisture content of the clean coal product.

Al1 four of the operating problems discussed in this paper have been corrected or is in the process of being corrected as of the writing of this report. None of the problems has resulted in termination of the testing program. The DOE POC is operational and processing coal on a daily basis.

The instrumentation in the DOE POC is rather sophisticated when compared to the instrumentation of a commercial coal preparation plant. All of the instruments installed worked properly with the exception of three systems. These three systems are the automatic slurry ash analyzer and pyrite detection unit, the automated flocculant control systems for both thickeners, and 1astly, the density indicating meters for control of reagent addition to advanced flotation cell and flocculant to the refuse belt press.

The density indicating meters are nuclear density gauges attached to the outside of the pipe to be measured. During calibration, it was determined that the accuracy required could not be obtained from the present installation arrangement. The revision requires the installation of " $Z$ " sections in the pipe to be measured. However, the longer site section of the nuclear density gauge requires larger sources to obtain accurate results.

There are four (4) nuclear density gauges installed in the DOE POC, each requiring modifications to piping by installing " $Z$ " sections and larger nuclear sources. This was ongoing during the report period. Again, the problem is not insurmountable, and all systems are being operated manualiy until the permanent solutions can be installed.

The automated flocculant control system has been delivered and installed during the operating period, but not operated until a service representative can be on site for debugging and placing the two systems on line. Again, this has not prevented operation because the flocculant pumps are being operated manually.

The slurry ash analyzer and pyrite detection instrument was found to contain a faulty detection device. This was returned to the manufacturer who requested and received permission to supply an updated detector. The downside of this is that it would require several weeks to manufacture and should be instalied and operational 
by mid May. This instrument is incorporated into the instrumentation to provide real time monitoring of the performance of the advanced flotation cell and is not involved in any control 1oop.

The test plan developed by ICF KE and approved by DOE is very aggressive. The plan calls for operating the DOE POC and OCDO to perform at least two tests per day, with some test programs requiring three tests per day. In order to accomplish this pace, the laboratory analysis must be completed overnight and results provided by 7:00 a.m. the morning following the test day.

Several commercial coal testing laboratories were requested to bid the analytical work on this basis. Two very competent companies returned bids meeting the requirements of rapid turnaround results.

During the initial testing, samples were produced and analyzed by the successful bidder for the analytical contract. However, the results reported did not make sense in the majority of reported values. An investigation as to why led to the following conclusions. The primary reason for poor results was sample preparation. The problem resulted from attempting to handle too large of a primary sample and the problem of broken liners in the steel drums used for sample collection. A sample was collected and split three ways. Each lab performed the analytical work and reported the results. These results are shown on Table 13.1 "Comparison of Laboratory Results."

There are differences between results, and in order to improve the final lesults, ICF KE recommended to the commercial laboratory to improve their $Q A / Q C$. In addition, ICF $K E$ purchased 20-gallon plastic containers and began to take smaller total samples by limiting the number of sample cuts per test. The number of sample cuts were never reduced below the requirements of the test plan which were eleven cuts per test per sample stream.

Based on the above, one would determine that the operation of the OCDO facility and DOE POC facility is not functional. However, this is not the case. The fact is that the plant has operated consistently three, and sometimes as many as five, days per week and 8-10 hours per day at or above the feed and product tonnage.

The month of March resulted in the completion of test work on the heavy media cyclone, the hydrcicyclone, and the beginning of testing the conventional froth flotation circuit. The goal of each of these conventional unit operations was to remove as much high ash, high sulfur, low Btu reject before entering the advanced flotation DOE POC facility. The requirements were that each of the conventional unit operations would recover $97 \%$ of the raw coal Btu.

The heavy media cyclone is the first cleaning unit operation in the circuit. Four tests were conducted on the heavy-media cyclone over a range of specific gravities from 1.70 to 1.85 . The determining factor was the lowest specific gravity that produced the $97 \%$ Btu recovery. the results are shown in Table 13.2, "Heavy Media Cyclone 

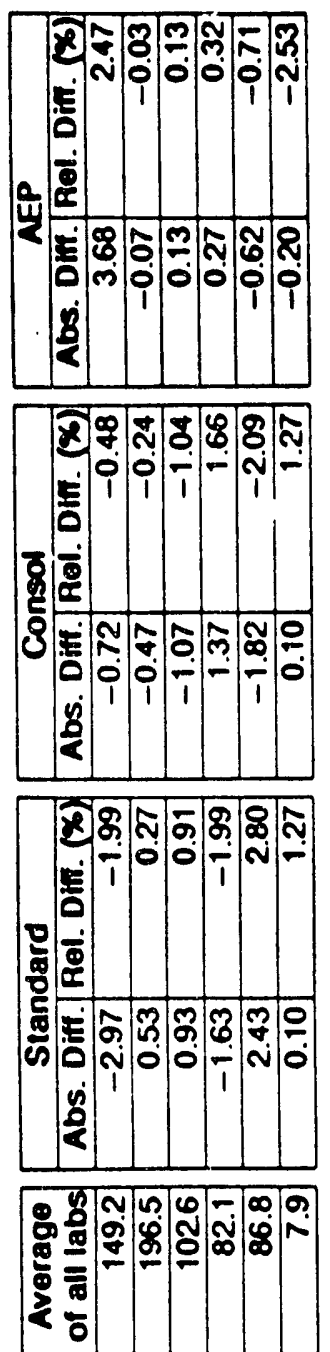

닌

年

(N) 니용요

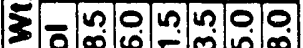
हुㅇㅇ

Omón \%

क

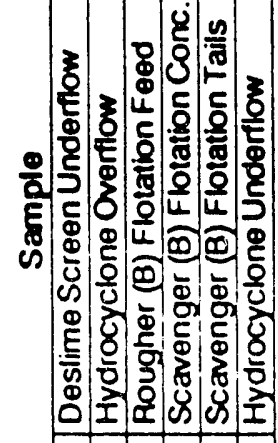

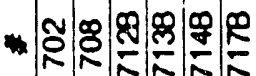
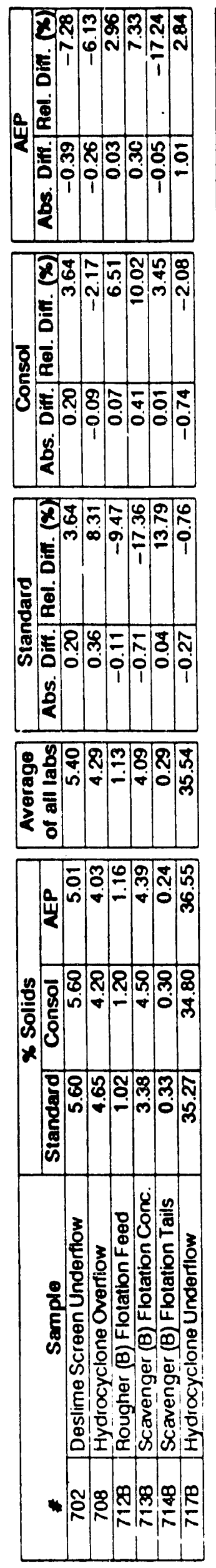
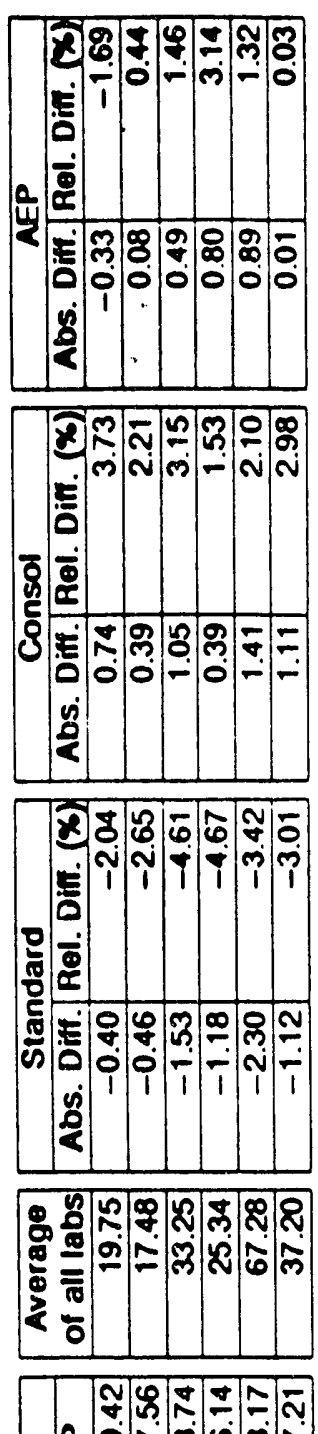

प्र

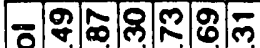
บุ 2.
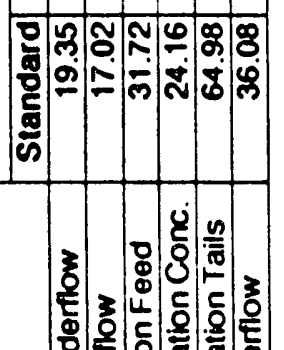
은

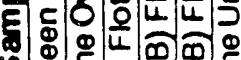
ڤ)

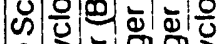

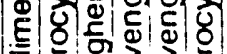
ज़ ड द्व

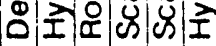
ํํㅇㅛㅛ
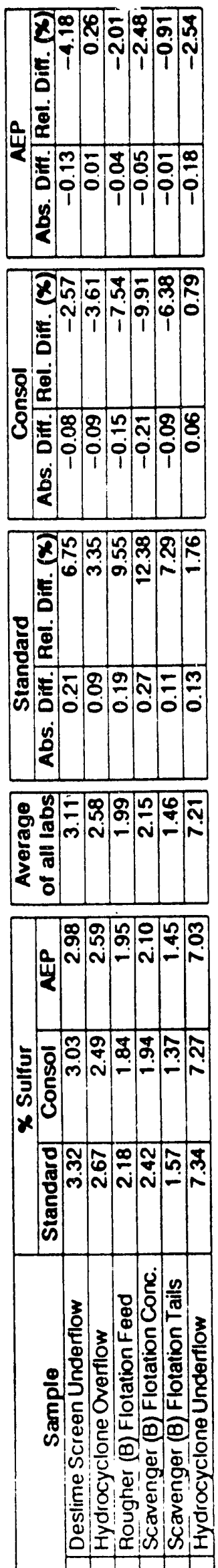

-
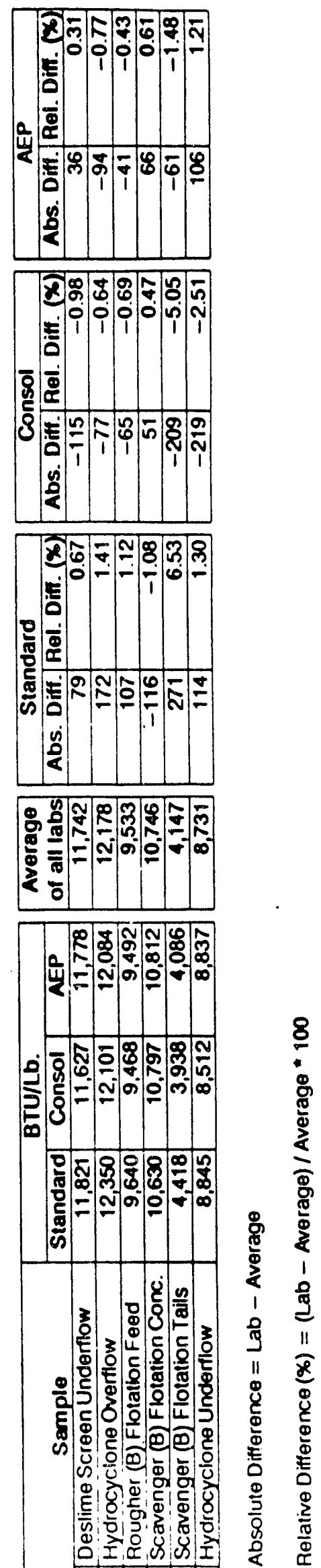

요용

ํㅗㅇ 
Test Results." The results show that with 1.70 specific gravity, the Btu recovery of $96.95 \%$ is accomplished. This will be the specific gravity used in the remainder of the test program.

The product of the heavy media cyclone is crushed in a closed circuit to minus 48 mesh and combined with the natural 48 mesh $x$ zero and processed by the hydrocyclone. The hydrocyclone is used to remove high ash, free pyrite and low Btu. The results of the test program are shown on Table 13.3, "Hydrocyclone Test Results." The best results were test 93031002 with a one inch apex, three inch vortex finder, seven inches long. Additional testing was conducted in an attempt to improve the ash of the underflow. All results were only incremental and resulted in the selection of the beforementioned test. The program was placed at least one week behind schedule because of this additional testing.

The heavy-media cyclone and hydrocyclone were operated at the required conditions, and testing began on conventional flotation. The conventional flotation circuit was first tested for one day to determine if a grab-and-run product could be obtained. The POC scale results were the same as the Task 5 results in that no product of acceptable pyritic sulfur could be produced.

Towards the end of this reporting period, the conventional flotation system was tested to determine correct reagent dosage and not upset the recycled water. The results of one of these tests, which are typical, are shown in Table 13.4, "Conventional Flotation test Results." The weight recovery and Btu recovery were extremely low. This was completely unacceptable.

The month of March concluded with a discussion of alternatives available to the team to eliminate the loss of Btu from conventional flotation. A mini-test program was established to evaluate conventional flotation in split circuit against the full stream flotation in the advanced column flotation cell after grinding. It was determined that this mini-test program would put the test plan further behind schedule, but the benefits of the correct decisions should outweigh the delay.

At the conclusion of the month of March, all of the problems identified during the operation of the OCDO and DOE POC facilities were either corrected or plans and/or changes implemented to correct the problems.

The testing program produced results on the Pittsburgh No. 8 coal that established the operating conditions for the heavy-media cyclone, the hydrocyclone, and a mini-test plan for comparing conventional flotation with advanced column flotation to improve overall Btu recovery.

The testing program will continue into the next quarter according to the POC Test Plan. 
TABLE 13.2

HEAVY MEDIA TEST RESULTS

\begin{tabular}{|l|r|r|r|r|}
\hline \multicolumn{1}{|c|}{ PARAMETER } & & & & \\
\hline & & & & \\
\hline TEST NUMBER & $\mathbf{9 3 0 3 0 8 0 3}$ & $\mathbf{9 3 0 3 0 8 0 4}$ & $\mathbf{9 3 0 3 0 8 0 5}$ & $\mathbf{9 3 0 3 0 8 0 6}$ \\
\hline GRAVITY & 1.70 & 1.75 & 1.8 & 1.85 \\
\hline PRESSURE & $14 \mathrm{PSI}$ & $13 \mathrm{PSI}$ & $13 \mathrm{PSI}$ & $12 \mathrm{PSI}$ \\
\hline FEED ASH & 28.40 & 28.78 & 28.3 & 28.74 \\
\hline FEED BTU & 10201.00 & 10077 & 10225 & 10165 \\
\hline COAL ASH & 11.15 & 11.48 & 11.83 & 11.53 \\
\hline COAL BTU & 13103.00 & 13067 & 13113 & 13123 \\
\hline REJECT ASH & 81.49 & 81.8 & 83.71 & 83.36 \\
\hline REJECT BTU & 1524.00 & 1538 & 1324 & 1436 \\
\hline ASH YIELD & $75.48 \%$ & $75.40 \%$ & $77.09 \%$ & $76.04 \%$ \\
\hline BTU RECOVERY & $96.95 \%$ & $97.77 \%$ & $98.86 \%$ & $98.17 \%$ \\
\hline
\end{tabular}

TABLE 13.3

HYDROCYCLONE TEST RESULTS

\begin{tabular}{|c|c|c|c|}
\hline PARAMETER & & & \\
\hline TEST NUMBER & 93031002 & 93031701 & 93031901 \\
\hline APEX DIAMETER & 1 & 1 & 1 \\
\hline PRESSURE & 14.5 PSI & $15 \mathrm{PSI}$ & 14.5 PSI \\
\hline VORTEX DIAMETER & 3 & 2.5 & 3 \\
\hline VORTEX LEGTH & 7 & 7 & 10.5 \\
\hline FEED ASH & 20.09 & 20.34 & 21.42 \\
\hline FEED BTU & 11725 & 11487 & 11544 \\
\hline COAL ASH & 19.99 & 17.6 & 21.33 \\
\hline COAL BTU & 11574 & 12159 & 11478 \\
\hline REJECT ASH & 33.32 & 35.44 & 35.31 \\
\hline REJECT BTU & 9492 & 8993 & 9119 \\
\hline ASH YIELD & $99.25 \%$ & $84.64 \%$ & $99.36 \%$ \\
\hline BTU RECOVERY & $97.97 \%$ & $89.59 \%$ & $\mathbf{9 8 . 7 9 \%}$ \\
\hline
\end{tabular}

TABLE 13.4

CONVENTIONAL FLOTATION TEST RESULTS

\begin{tabular}{|c|c|c|c|}
\hline PARAMETER & 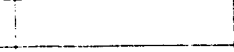 & & \\
\hline FLOTATION CELL & & COAARSE & FINE \\
\hline FEED ASH & & 14.82 & 38.76 \\
\hline FEED BTU & & 12625 & 8723 \\
\hline COAL ASH & & 11.89 & 25.62 \\
\hline COAL BTU & & 12946 & 10912 \\
\hline REJECT ASH & & 17.49 & 53.5 \\
\hline REJECT BTU & & 12193 & 6321 \\
\hline ASH YIELD & & $47.68 \%$ & $52.87 \%$ \\
\hline BTU RECOVERY & & $48.89 \%$ & $66.14 \%$ \\
\hline
\end{tabular}




\subsection{TASK 14 THROUGH TÁSK 16}

14.1 Review of Work Completed this Quarter

No wort was planned or ccmpleted during this quarter. 

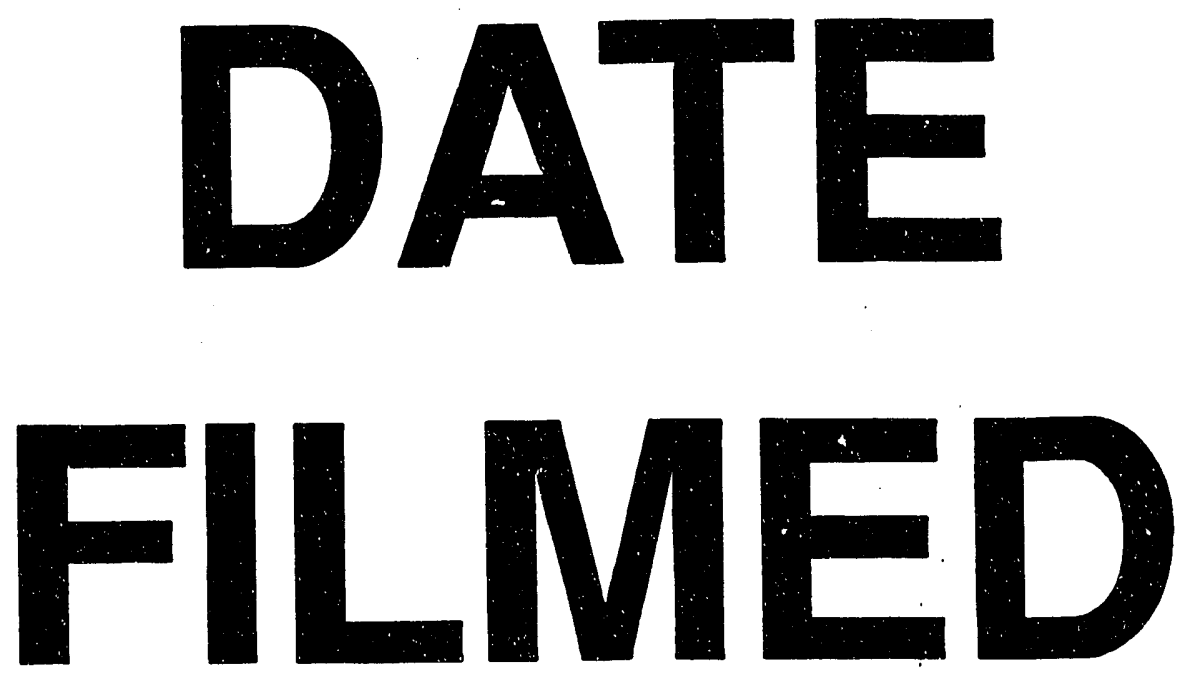

$8 / 24 / 93$
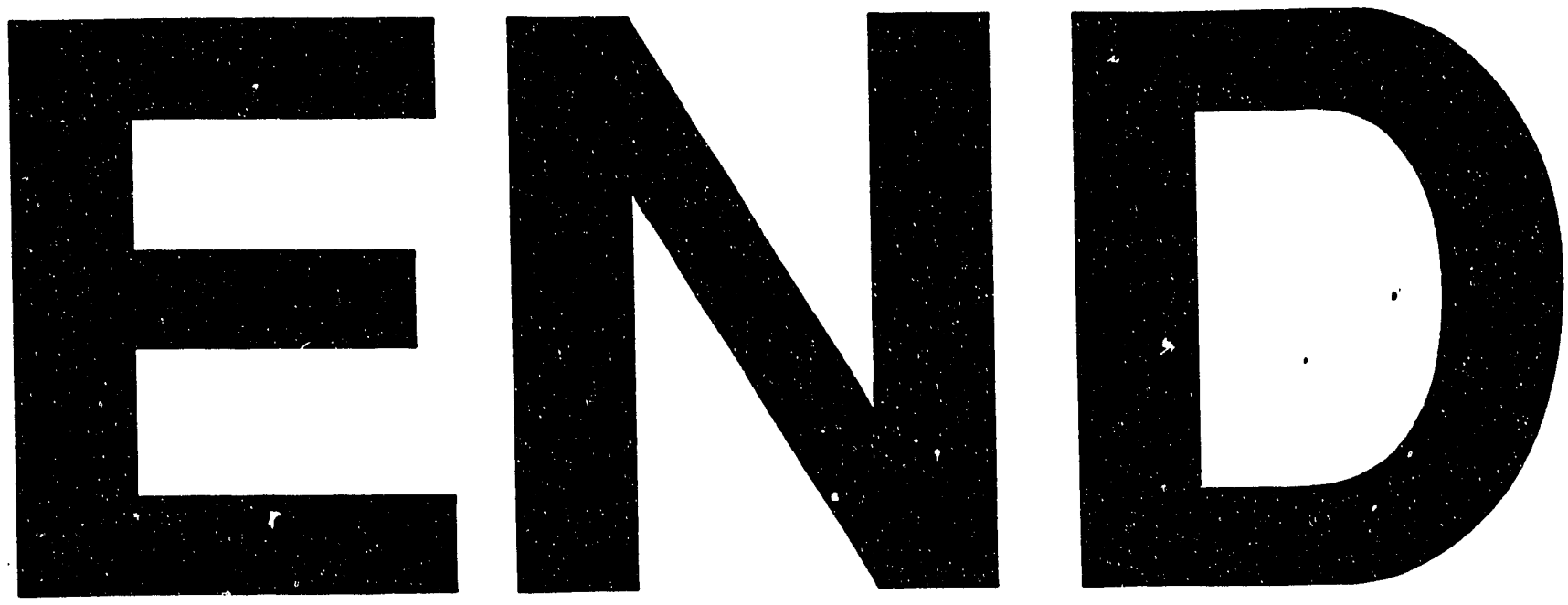
